\title{
The Ideology of Climate Change Denial in the United States
}

Jean-Daniel Collomb

\section{OpenEdition}

Journals

Édition électronique

URL : https://journals.openedition.org/ejas/10305

DOI : 10.4000/ejas.10305

ISSN : 1991-9336

Éditeur

European Association for American Studies

Référence électronique

Jean-Daniel Collomb, «The Ideology of Climate Change Denial in the United States », European journal of American studies [En ligne], 9-1 | 2014, document 5, mis en ligne le 01 avril 2014, consulté le 08 juillet 2021. URL : http://journals.openedition.org/ejas/10305 ; DOI : https://doi.org/10.4000/ejas. 10305

Ce document a été généré automatiquement le 8 juillet 2021.

Creative Commons License 


\title{
The Ideology of Climate Change Denial in the United States
}

\author{
Jean-Daniel Collomb
}

The ideological underpinning of climate change denial in the United States merits closer scrutiny than it has received to date. American opponents and critics of the scientific consensus over man-made global warming have been much more vocal and influential than their counterparts in continental Europe; in France several scientists and intellectuals ${ }^{1}$ do take issue with the positions of the Intergovernmental Panel on Climate Change (IPCC) but they tend to be rather isolated and marginal figures with little or no impact on public policy. By contrast, American climate change deniers have been remarkably successful in confusing public opinion and delaying decisive action. They receive considerable media attention and enjoy access to key Washington power brokers. Therefore, it is worth analyzing the origins of this powerful movement in order to see what really drives climate change denial in the United States. It is very often claimed, with good reason, that climate sceptics are beholden to powerful corporate interests such as those of the Koch brothers. ${ }^{2}$ Ties between corporations and conservative and libertarian think tanks ${ }^{3}$ have been well-documented. There is no denying that, in the short term, some industries, such as the coal industry, have a vested interest in averting any government plan to reduce carbon emissions.

It is my contention that the emphasis placed on the efforts of the fossil fuel industries to promote their short-term economic self-interests should be complemented by other important factors. First, there is an ideological dimension to the effort to counter climate action: the conservative movement appears to be committed to small government and free enterprise as ideological ends in themselves, irrespective of economic and environmental common sense. From the smallgovernment perspective, therefore, discrediting calls for strong national and international climate action has become a matter of ideological survival. Second, another factor complicates the matter even further for Bill McKibben, Al Gore, and their followers: the defence of the American way of life defined as the dedication to permanently expanding economic prosperity and consumption has now become a 
highly convenient line of attack for climate change deniers. The American way of life is clearly an ideology all the more potent because it is not recognized as such by most Americans. In fact, enjoying a clean environment is high on the average voter's wish list. ${ }^{4}$ Embracing high environmental standards out of principle is one thing, however, accepting subsequent far-reaching and significant lifestyle changes in the form of higher gas prices or reduced mobility, for instance, is quite another, a fact acknowledged by both climate change deniers and the Obama administration.

\section{BACKGROUND}

The conservation of natural resources as a federal prerogative emerged during the Progressive era under the presidency of Theodore Roosevelt (1901-1909): the US Reclamation Service (1902) and the US Forest Service (1905) became a blueprint for the creation of countless federal conservation agencies throughout the $20^{\text {th }}$ century. The Forest Service, under the mindful direction of Gifford Pinchot, was given the mandate of managing the forest reserves, later renamed national forests, which had been set aside in the early 1890s. These developments constituted a major watershed in the role of the federal government in the management of the public domain. Hitherto, public officials had been eager to privatize the federally held lands as quickly as possible so that various special interest groups could improve and develop the land as they saw fit. Environmental destruction and waste on a large scale had convinced Theodore Roosevelt that the federal government needed to take an active role in managing natural resources. ${ }^{5}$ If the origins of American conservation date to the late $19^{\text {th }}$ century, the modern environmental movement arose in the late 1960s and early 1970s when American environmentalists ceased to devote all of their attention and efforts to wilderness preservation and began to address quality-of-life issues. ${ }^{6} \mathrm{~A}$ flurry of environmental laws such as the Clean Air Act (1963), ${ }^{7}$ the Clean Water Act (1972), ${ }^{8}$ the Endangered Species Act (1973), ${ }^{9}$ the proclamation of an annual Earth Day (1970), as well as the creation of the Environmental Protection Agency (1972) ${ }^{10}$ to serve as a long awaited federal environmental watchdog, all bear witness to the public's growing environmental awareness at the time. Most recently, concerns raised by the scientific community about the issue of global warming have led strong environmentalists such as Bill McKibben and $\mathrm{Al}$ Gore to seek new legislation to curtail its negative impacts on the planet. Meanwhile some conservatives such as James Inhofe and Joe Barton have been doing their utmost to counter the myriad of environmental regulations and safety standards passed by Congress during the 1960s and 1970s and future environmental legislation. ${ }^{11}$

\section{A CASE OF LEGAL BRIBERY}

In the 1970s eager to protect its activities from regulations and above all its profit margins, corporate America began to challenge the growing influence of environmental organizations and other advocacy groups who had been instrumental in ushering in this golden age of environmental legislation..$^{12}$ Corporate leaders drew their inspiration from the successful tactics of the tobacco industry to thwart any restrictions on their activities: Naomi Oreskes and Erik M. Conway use the term "tobacco strategy" to explain how corporations set up or fund seemingly independent 
think tanks and hire experts and scientists in order to discredit scientific research and evidence likely to justify governmental regulations on their activities..$^{13}$ Needlessly to say, this constitutes a complete perversion of the scientific process, as the goal results in the fact that no scientifically-based call for environmental or safety regulations go unanswered and doubt is cast on the consensus reached in peer-reviewed scientific research. The climate change denial movement is part and parcel of this larger corporate effort to hinder regulations. ${ }^{14}$

Since the 1990s critics of climate scepticism have been striving to draw the public's attention to the seamy side of the movement: its incestuous connection with the fossil fuel industries whose overriding objective is, they claim, to forestall government action by confusing public perceptions of the scientific evidence at hand. In The Assault on Reason (2007) former Vice-President Al Gore accused powerful corporations like Exxon Mobil of being determined to skew and pervert the scientific process:

Wealthy right-wing ideologues have joined with the most cynical and irresponsible companies in the oil, coal, and mining industries to contribute large sums of money to finance pseudoscientific front groups that specialize in sowing confusion in the public's mind about global warming. They issue one misleading 'report' after another, pretending that there is a significant disagreement in the legitimate scientific community in areas where there is actually a broad-based consensus. ${ }^{15}$

Gore reiterated his critique in even harsher terms four years later in an article in Rolling Stone castigating the Senate for being "controlled lock, stock and barrel by the oil and coal industries," making any hope of climate action a distant prospect. ${ }^{16}$ More recently Gore's assessment has been echoed by the climate scientist Michael E. Mann ${ }^{17}$ whose book The Hockey Stick and the Climate Wars questions the scientific integrity of Patrick J. Michaels and Fred Singer, two of the leading experts who attack the theory of man-made global warming: Mann points to the funds Michaels and Singer allegedly received from the energy sector. ${ }^{18}$

Allegations of corporate manoeuvres in an attempt to weaken environmental regulations are documented in the data collected by the Center for Responsive Politics. A peak in campaign contributions from the energy sector occurred in 2009 as Congress was considering passing a cap-and-trade ${ }^{19}$ bill which would have been a crucial and long-awaited first step towards an American commitment to serious climate action. ${ }^{20}$ The American Coalition for Clean Coal Electricity (ACCCE), a well-heeled advocacy group representing coal producers, among others, invested massively in the 2008 presidential election. ${ }^{21}$ Four years later, Republicans received a significantly larger amount of money from the fossil fuel industries than their Democratic colleagues: Barack Obama received \$710,277 in 2011-2012 while Mitt Romney's campaign pocketed $\$ 4,763,934$ during the same period. ${ }^{22}$ Needless to say, the contest between those industries and environmental organizations is uneven: in 2011, it is estimated that all oil and gas interests invested $\$ 149,169,677$ in lobbying ${ }^{23}$ whilst overall contributions from US environmental organisations amounted to $\$ 18,125,119 .{ }^{24}$ It is also worth noting that fossil fuel money does not just go to elected officials and candidates. Oil and gas companies have been contributing lavish sums of money to conservative and libertarian think tanks for several decades with the two-fold goal of ensuring not only that elected officials and public figures remain sympathetic to the interests of the fossil fuel industries, but that they are provided with the expertise and the scientific evidence they need to be able to counter arguments by the proponents of environmental regulations as well. Hence, the conservative Washington think tanks 
such as the Competitive Enterprise Institute and the Heritage Foundation are among the biggest recipients of oil and gas money. Peter J. Jacques, Riley E. Dunlap, and Mark Freeman have also demonstrated that corporate interests are funding indirectly antienvironmental expertise by bankrolling conservative think tanks: of 141 environmentally-sceptic books written between 1972 and 2005, only 11 were not linked to corporate-funded conservative think tanks. ${ }^{25}$ It is therefore undeniable that the climate change denial movement stems from a concerted effort on the part of fossil fuel industries to protect their economic self-interests from government regulation. Yet there appears to be more to the climate change denial movement than the mere defence of economic self-interest.

\section{A MATTER OF IDEOLOGICAL SURVIVAL}

The climate change denial movement in the United States attracts smallgovernment advocates as well as social conservatives and members of the so-called religious Right. The latter have assumed centre stage since the early 1980s, focusing on issues of morality: they have been instrumental in bringing about the so-called culture wars through their positions on a wide range of issues-abortion, same-sex marriage and, more recently, stem cell research. Although conservative activists sometimes find common ground among themselves, social conservatives ought not to be confused with their fiscal counterparts, also known as small-government conservatives, nor with libertarians whose main political aim is to reduce drastically the size and prominence of the federal government and give business a free rein. A few notable exceptions notwithstanding, ${ }^{26}$ the effort to question the validity of the theory of man-made global warming has been spearheaded largely by the admirers of Barry Goldwater and Jack Kemp rather than the disciples of Jerry Falwell and Pat Robertson. The Heartland Institute, the Heritage Foundation and the Cato Institute, all conservative and libertarian think tanks, have also joined the fray in addition to the well-funded advocacy groups Americans for Prosperity and Americans for Tax Reform. Such a broad range of organizations suggests that the climate war is part of the larger campaign launched by fiscal conservatives in the 1970s to counter the environmental movement's agenda.

Small-government advocates usually declare that they value the health of the land and support high environmental standards. They claim to disagree with the environmental community on the means, but not on the ends. They argue, in a counter-intuitive way, that the best way to protect the environment is by maximizing economic freedom and eliminating government. This can be achieved, they suggest, by the consolidation of private property rights which will foster good stewardship since private land owners have more incentives than do government bureaucrats to take care of the land they own. ${ }^{27}$ Jay Wesley Richards of the Heritage Foundation asserts that "sometimes environmental regulation is in order, but more often than not, there are market-based solutions that work better. For instance, strong private property laws are often the best ways to encourage people to act in environmentally friendly ways. We tend to act less responsibly when we are not directly affected by our actions." ${ }^{28}$

Far from being a means to an end and a way to achieve the good society, the conservative movement's commitment to small government and free markets seems to have become an end in itself and almost a secular religion. Over the last few years, no 
social movement has epitomized this attitude better than the Tea Parties, who came into being in the wake of the financial meltdown in 2008. It is undeniable that economic issues are much more central to Tea Party activism than social ones. ${ }^{29}$ In their Tea Party manifesto Dick Armey and Matt Kibbe express their aversion to government regulations in no uncertain terms: "For us, it is all about the rights of the individual over the collective." ${ }^{30}$ The Tea Party movement's discourse is in keeping with the longstanding American tradition of anti-government rhetoric going back all the way to the Anti-Federalists. It is no wonder that cap and trade quickly became one of their bêtes noires. Armey and Kibbe blasted this climate bill as a sly attempt on the part of the President and his party to "'Europeanize' the United States." ${ }^{31}$ They give short shrift to the scientific consensus on man-made climate change because the notion that the federal government ought to step in so as to avert an environmental Armageddon threatens to undermine the entire intellectual edifice of the Tea Party movement. In order to grasp the stakes of the climate war, it is useful to consider the words of the prominent environmental philosopher J. Baird Callicott:

It will not suffice ... simply to encourage people individually and voluntarily to build green and drive hybrid. But what's worse is the implication that that's all we can do about it, that the ultimate responsibility for dampening the adverse effects of global climate change devolves to each of us as individuals. On the contrary, the only hope we have to temper global climate change is a collective sociocultural response in the form of policy, regulation, treaty, and law. ${ }^{32}$

11 The contrast between Dick Armey's rabid fear of government and Callicott's insistence on the need for a government-sponsored international concerted effort could not be starker.

Global warming poses a philosophical challenge to libertarians and smallgovernment conservatives: their world view is premised on the idea that government power should always be held in check lest it destroy individual freedom while the world is faced with a crisis of global proportions that could only be averted by a strong and prolonged government action. The steps necessary to address the challenges posed by global warming would lay waste to the Tea Party's ironclad faith in the free market as the ultimate problem-solver. As Naomi Oreskes states: "Accepting that by-products of industrial civilization were irreparably damaging the global environment was to accept the reality of market failure. It was to acknowledge the limits of free-market capitalism." ${ }^{33}$ Given such circumstances, denial appears to be a more desirable strategy than a devastating reappraisal of one's deeply held beliefs. In that regard, the climate denial movement clearly emerges as a case of ideological grandstanding. As a matter of fact, a significant number of American corporations, by definition dedicated to freemarket economics, have already jumped on the global warming bandwagon. The US Climate Action Partnership, set up by several major corporations in cooperation with various environmental organisations in 2007, is a case in point. ${ }^{34}$ What is at stake are the intellectual underpinnings of libertarianism and small-government conservatism. Their most zealous proponents are not prepared to surrender without putting up a fight.

Michael Gerson, Washington Post columnist and former speechwriter for President George W. Bush, has pointed out that the political controversy over man-made global warming is the most recent front in the so-called culture wars. ${ }^{35}$ Whether correct or not, Gerson's idea bears testimony to the vehement rhetoric deployed by climate change deniers against their detractors, and vice versa. The climate change denial 
movement sometimes appears as the extension of Cold War politics by other means. Deniers are prone to dismiss the theory of man-made global warming and all the attendant government schemes to mitigate it as a kind of socialist conspiracy hatched by the enemies of economic freedom. Michael Crichton's novel State of Fear is a good example as it casts global warming as a ploy to impose strong government intervention on the American people and suppress free enterprise. ${ }^{36}$ Oklahoma Senator James Inhofe, the most vocal climate change denier in the Upper House, asked Crichton to testify before the US Senate Committee on Environment and Public Works in 2005. ${ }^{37}$ The idea of a statist conspiracy to stifle entrepreneurship combined with dire warnings about "environmental socialism" also resonates with the guests and anchors of rightwing talk shows like Rush Limbaugh's and Glenn Beck's.

14 This being said, climate denial is not confined to popular culture: it has also been advocated by prominent conservative intellectuals. George F. Will, in a 2010 Washington Post column, derided the threat of global warming as a convenient strategy used by biggovernment liberals like $\mathrm{Al}$ Gore and Barack Obama to reinforce what he perceives as the pre-eminence of statism in American life and to drive the last nail in the coffin of economic freedom. He characterises public figures endeavouring to draw the public's attention to the dangers posed by the warming of the planet as "those trying to stampede the world into a spasm of prophylactic statism." ${ }^{38}$ The fear of socialism by stealth, which has been on the conservative fiscal agenda since the end of the Cold War, has been summarized laconically by the conservative lobbyist and zealous climate change denier Steve Milloy: "green is the new red." ${ }^{39}$ In a more restrained manner, the influential conservative intellectual Charles Krauthammer offered a variation on the same theme in a 2008 Washington Post article: although he was careful to describe himself as a "global warming agnostic," he was quick to cast suspicions on the motives behind the effort to avert climate change: "Just as the ash heap of history beckoned, the intellectual left was handed the ultimate salvation: environmentalism. Now the experts will regulate your life not in the name of the proletariat or Fabian socialism but-even better-in the name of Earth itself." ${ }^{40}$ The fact that such prominent figures as George F. Will and Charles Krauthammer should have towed-albeit tentatively in Krauthammer's case-the climate change denial line serves to suggest that this concerted effort cannot be dismissed as a fringe phenomenon.

Climate change deniers have been remarkably successful in shaping the position of the Republican Party with regards to global warming. During the 2012 presidential primary contest, each candidate had to pass a number of ideological litmus tests in order to prove his or her conservativeness on key issues like illegal immigration, abortion, and same-sex marriage. Curiously, denying man-made global warming or downplaying its consequences turned out to be one of the requirements foisted on the candidates. Mitt Romney, who eventually became the Republican nominee, remains a case in point. Neela Barnjee, reporter for the Los Angeles Times, has shown that, although Romney had been pro-active on climate policy at the beginning of his term as Governor of Massachusetts (2003-2007), he had no compunction about changing his position when he first decided to run for president in $2008 .{ }^{41}$ To take but one example, in 2005 he distanced himself from a regional compact known as the Regional Greenhouse Gas Initiative (ReGGIe) created by New England states with a view to reducing carbon emissions in the region, a move all the more noteworthy as Romney had been instrumental in its initial development. Romney does not deny in his 2010 book No Apology that the Earth is warming but he claims to be uncertain about the 
extent of human responsibility in the warming and discards cap-and-trade legislation as a set of "feel-good policies" which will fail to make a difference, thereby echoing a theme already well-rehearsed in conservative and libertarian circles. ${ }^{42}$ Did Romney genuinely change his mind on the substantive matters involved in this issue or, is it more likely that his sudden change of heart reflects the difficulty of being an advocate of serious climate action inside the Republican Party? Once again, the climate controversy is just one arena of contention in the multifaceted effort to protect American corporations and business owners from government regulations.

Ronald Brownstein has noted over the last few decades, and especially since the triumph of Newt Gingrich's Contract with America in 1994, that the Republican Party has become significantly more conservative and more ideologically homogeneous and therefore is less liable to strike compromises than in the decades that followed World War II. ${ }^{43}$ The growing emphasis on ideological purity in Republican primaries and among activists has made it possible for climate change deniers to wield a disproportionate influence within a party which routinely represents about half of the electorate. Meanwhile, moderate and middle-of-the-road Republicans willing to embrace necessary and desirable regulations on business activities are being sidelined as exemplified by Senator Richard Lugar's downfall in an Indiana primary after a 30year term in the Upper House of Congress. Ideological intransigence also prompted Maine Senator Olympia Snowe to not seek a fourth term in 2012. John McCain, who unavailingly had co-sponsored several climate bills in the Senate before winning the Republican presidential nomination in 2008, did not even mention global warming in his acceptance speech at the Republican Convention in Saint Paul, Minnesota. The rub for the Republican Party is that although market fundamentalism may play well during some Republican primaries across the country, it is unlikely to be a winner with the larger electorate in the general elections, which Mitt Romney found out in 2012. What may be more appealing to the general public, however, is the opposition to climate legislation in defence of the so-called American way of life.

\section{THE AMERICAN WAY OF LIFE OR THE LAST REFUGE OF A CLIMATE CHANGE DENIER}

The effort to undermine the credibility of scientific research on man-made global warming has continued since the early 1990s after the IPCC had started calling the alarm. Nevertheless because of mounting scientific evidence ${ }^{44}$ it is becoming increasingly untenable to deny reality, which has led conservative and libertarian think tanks to modify their tactics. Increasingly, to paraphrase James Hoggan, "nondenier deniers" are replacing "deniers". These nondenier deniers are "people who put themselves forth as reasonable interpreters of the science, even as allies in the fight to bring climate change to the public's attention. But then they throw in a variety of arguments that actually undermine the public appetite for action." ${ }^{45}$ Libertarian and conservative climate experts increasingly recoil from denying the fact that the planet is warming, but they usually lose no time in qualifying their acceptance with two caveats. First, they assert that the negative repercussions of a global rise in temperatures are being grossly overstated in order to alarm the public and decision-makers into accepting the environmentalist agenda. Second, nondenier deniers argue that actions to mitigate the effects of global warming will be economically destructive and 
environmentally insignificant. Consider the testimony of Kenneth P. Green of the American Enterprise Institute before the House Select Committee on Energy Independence and Global Warming in December 2010: "It is time policymakers recognize that despite the claims of renewable energy and efficiency hucksters, we do not have the technologies needed to significantly curb greenhouse gas emissions without causing massive economic disruption." ${ }^{16}$ Green goes on to demand additional deregulation so that the American people will face fewer obstacles as they adapt to the consequences of climate change. The commitment to adaptation rather than mitigation has been repeated endlessly in recent conservative and libertarian publications and statements on global warming. ${ }^{47}$

There is no question that, taken in isolation, various points made by climate change deniers are well taken and ought to be seriously heeded by the proponents of strong climate action. Consider, for example, their repeated claim that a unilateral approach to climate change by the American government would make no real difference, an argument often used to discredit efforts by Congress to impose mandatory reductions in greenhouse gas emissions across the nation. Sallie James argues that cap and trade is a losing proposition because it would have an insignificant impact on the earth's temperatures while damaging the competitiveness of the American economy. ${ }^{48}$ Derrick Morgan raises similar objections ${ }^{49}$ about a national putative carbon tax, also warning that such a measure would blunt the benefits currently derived by the American economy from the shale gas boom. ${ }^{50}$ Moreover, Nicolas Loris and Brett D. Schaefer contend that placing the largest burden of reducing greenhouse gas emissions on developed countries like the United States makes less and less sense as developing countries, such as India or China, will soon overtake the United States as the world's chief emitters of carbon dioxide..$^{51}$

The fear that strong climate action might reduce American competitiveness with rising giants like China is undoubtedly one of the strongest reasons why the Senate refused to ratify the Kyoto Protocol in 1997. Senators Robert Byrd (West Virginia) and Chuck Hagel (Nebraska) issued a resolution blocking the ratification of the Kyoto protocol, invoking the same line of argument. In his scathing indictment of the 2009 Copenhagen Climate Change Summit, Steven Groves, of the Heritage Foundation, took exception to the fact that, under the terms of a Kyoto II climate change treaty, the United States would be required to help emerging economies, including China-its main economic rival, improve their environmental standards by sharing American findings in clean energy research. ${ }^{52}$ Groves reiterates his warning against American naiveté in climate negotiations:

Developing nations, including economic giants such as India and China, view climate change as a cash cow...and more. In addition to 'milking' developed nations for hundreds of billions of dollars in aid, they'll receive, absolutely free, cleanenergy technology worth untold billions more. ${ }^{53}$

Earlier in 2009 Derek Scissors also dismissed the notion that China would follow in the footsteps of the United States if only America took the lead, as "a climate change fable. ${ }^{54}$ Needless to say, the hard-hitting stance of the Chinese delegation at the Copenhagen conference and their disrespectful treatment of President Barack Obama ${ }^{55}$ appear to have corroborated the warnings issued by the Heritage Foundation's climate change experts. In the context of the economic difficulties faced by the American economy since 2008 and in light of the strong Chinese economy, it is at the very least problematic to require the United States to engage in serious measures concerning 
climate change action with no certainty that the Chinese will also be required to do their fair share.

Of particular concern to climate sceptics has also been the defence of American national sovereignty: they contend that an American commitment to a multilateral approach to the climate crisis would inevitably lead to a major loss of US autonomy. Steven Groves contends that under the terms of a Kyoto-style treaty, the United States would be marginalised and exploited by other nations:

A committee (or committees) of international experts-whose members may include representatives from overtly hostile nations-will have the final word on whether the US climate record is up to snuff. ... Just as 'developing world' nations dominate other UN bodies such as the General Assembly and the Human Rights Council, so they will dominate the new international climate bureaucracy and enforcement committees. ${ }^{56}$

Steven Groves further argues the unconstitutionality of the ratification of the Copenhagen treaty by the US Senate. ${ }^{57}$ Although his judgement about the constitutionality of the potential ratification of the Copenhagen treaty seems unjustified, his concern about the pitfalls of climate multilateralism cannot be discarded in the same light. Were the US Senate to ratify a Kyoto-style treaty, it would have to ensure governmental protection of American interests.

Various objections raised by climate change sceptics are well-taken. It is not unreasonable, for example, to demand that emerging economies, and especially the BRICS (Brazil, Russia, India, China, and South Africa), not be exonerated from the tremendous efforts necessary to deal with climate change, although the priority of climate change deniers appears to be to find arguments to stall any measure to address climate change. While they are quick to point out the futility of unilateral action on the part of the United States, they are also reluctant to endorse multilateral action. Taken together, these two positions give one the impression that taking no action continues to be the best course of action. The reason for this is that in matters of environmental policy, American fiscal conservatives and libertarians have tended to subjugate land health and high environmental standards to the imperatives of economic growth.

Ari Fleischer, then spokesman for the George W. Bush White House, replied to a journalist who asked him in 2001 whether American people ought to make lifestyle adjustments in order to remedy energy challenges, that, to paraphrase George H.W. Bush, the American way of life was not negotiable:

That's a big no. The President believes that it's an American way of life, and that it should be the goal of policy makers to protect the American way of life. The American way of life is a blessed one. And we have a bounty of resources in this country. What we need to do is make certain that we're able to get those resources in an efficient way, in a way that also emphasizes protecting the environment and conservation, into the hands of consumers so they can make the choices that they want to make as they live their lives day to day. ${ }^{58}$

In this case, the American way of life is clearly defined as the unlimited and ever expanding ability of all American citizens to indulge in material consumption. This is an aspect of the debate particularly embraced by climate change deniers because it allows them to stand for the creation of wealth and higher standards of living for the American middle class. Senator James Inhofe wrote that his mission was to protect the average consumer from higher prices and regulations in a 2011 article in Human Events. ${ }^{59}$ Three years earlier the well-heeled and highly influential free-market advocacy 
group Americans for Prosperity launched a No Climate Tax Pledge which described cap and trade as "a massive tax hike" and required elected officials who endorse it never to vote in favour of a bill creating a tax addressing global warming. ${ }^{60}$ Only a few days after Barack Obama won a second term, Republican Congressional leaders signed this pledge. 61

Jean Isaac, a sociologist at the Heartland Institute, recently endeavoured to drive the point home by characterising cap and trade as "a huge tax on energy" 62 in her book Roosters of the Apocalypse, claiming that the implementation of the environmental movement's agenda would amount to "economic suicide." ${ }^{63}$ She also charges American environmentalists with being hell-bent on curtailing high living standards and American prosperity rather than being genuinely willing to protect the environment. ${ }^{64}$ This theme also looms very large in Steve Milloy's Green Hell. As far as Milloy is concerned, defeating the environmental movement's agenda is not merely a way to protect individual freedom, but also a way to prevent environmentalists from liquidating the American way of life altogether: "If our energy supply were threatened, then all our comforts and conveniences that stem from it-in other words, the American way of life-would be endangered as well." ${ }^{65}$ The proponents of small government appear to be unmoved by J. Baird Callicott's caveat that "the human economy is a subset of ecology." ${ }^{66}$ Their position is often predicated on the assumption that economic growth must always come first and that protecting the environment can only be ancillary to growth. Even though there is little doubt that such an approach will lead to a dead end, it does make political sense in the short term: branding themselves as the intransigent advocates of the American way of life allows climate deniers to attack their adversaries from a position of strength.

To complicate matters, high-profile advocates of climate action like Al Gore and Barack Obama have sometimes been unclear about the radical social and economic adjustments that addressing the challenges posed by global warming would require. In The Assault on Reason, Al Gore seems to imply that the American dedication to high consumption and economic growth will not need to be called into question, that quite the opposite holds true:

The opportunity presented by the climate crisis is not only the opportunity for new and better jobs, new technologies, new opportunities for profit, and a higher quality of life. It gives us an opportunity to experience something that few generations ever have the privilege of knowing: a common purpose compelling enough to lift us above our limitations and motivate us to set aside some of the bickering to which as human beings we are naturally vulnerable. ${ }^{67}$

Barack Obama has also made several declarations to the same effect. Eric Pooley, author of The Climate War, begs to differ. Although he never claims that climate action would wreak economic havoc, he also makes it plain that such a policy would have farreaching repercussions on the average citizen's lifestyle, as suggested in his account of congressional debates over cap and trade: "On the day Waxman released his bill, the Senate passed another resolution 89-8, saying that any climate bill must achieve its goals 'without increasing gasoline or energy prices'-in other words, the Senate was only in favor of a climate bill that didn't do anything." ${ }^{6}$ Bill McKibben has also been straightforward about the profound change needed to make a difference:

To reduce the amount of $\mathrm{CO}_{2}$ pouring into the atmosphere means dramatically reducing the amount of fossil fuel being consumed. Which means changing the underpinning of the planet's entire economy and altering our most ingrained 
personal habits. Even under the best scenarios, this will involve something more like a revolution than a technical fix. ${ }^{69}$ warming in a more straightforward manner has a great deal to do with misgivings about the public's response. Raising public awareness about global warming is one thing, and it is hard enough, but convincing the public to change its behavior in order to avert global warming is quite another. In his account of the climate wars, Eric Pooley noted that Rahm Emanuel, President Obama's Chief of Staff during his first two years in office, urged the president not to spend political capital on a climate bill because it did not appeal to the public and it would therefore be a nonstarter in the Senate. ${ }^{70}$ That is partly the reason why President Obama decided to throw his political weight behind healthcare reform rather than cap and trade in his first term. To be sure it would be unfair to state that President Obama did nothing to address the climate crisis. As Michael Grunwald has documented in his account of Barack Obama's first term, the President allocated a considerable portion of stimulus money to invest in clean and renewable energies..$^{71}$ The fact remains that the Obama administration shied away from actively supporting the Waxman-Markey Bill because it was afraid of becoming unpopular. This attitude goes a long way towards accounting for the climate change deniers' emphasis on the putative costs of climate action. It also begs one crucial question: were Barack Obama and Rahm Emanuel right in thinking that the public would not have accepted the passage of a cap-and-trade bill?

Political scientist James Stimson appears to believe otherwise. Judging from the data collected regarding public attitudes towards environmental regulations, the American people tend to be less disinclined to support serious environmental measures despite their economic repercussions than Rahm Emanuel believes: "The public wanted and still wants environmental improvements, and it wanted it regardless of trade-offs. That's what the data show. Given a choice between doing more about the environment and anything else, the environment wins." 72 It should be noted that Stimson's comment is a general one about American attitudes towards environmental policy, and not about global warming per se. Yet, there is no question that his analysis of public opinion in the United States seems to contradict the assumptions underpinning President Obama's climate strategy. One may wonder whether Stimson's evidence proves that the public is environmentally-friendly as a matter of principle but would be actually unwilling to live with the actual consequences of strong environmental regulations, or whether Rahm Emanuel was wrong in assuming that American voters would punish legislators for taking tough action in favor of protecting the climate. Whatever the case may be, in 2009 many members of Congress-both Republicans and Democrats-gave credence to Emanuel's assessment of the state of public opinion. If in fact most Republicans were dead set against the Waxman-Markey Bill, a significant number of Democrats also proved lukewarm about the bill if not downright hostile to it. The 2012 campaign for re-election to the US Senate by Joe Manchin, a Democratic Senator from coal-rich West Virginia, is a case in point. He captured the attention of the commentariat with his campaign ad "Dead Aim" in which he expressed his rejection of climate legislation by shooting at a piece of paper bearing the inscription "cap and trade." ${ }^{73}$ Such clear-cut 
stands make the possibility of decisive climate action in the next four years very unlikely.

\section{CONCLUSION}

It is worth bearing in mind that the origins and motives of the American climate change denial movement are highly complex and cannot be merely described as the upshot of an attempt on the part of the energy sector to ward off regulation-although this interpretation sheds light on a large part of the movement. Climate change deniers also illustrate the strong ideological forces that have been shaping Republican politics over the last few decades. The generally accepted scientific explanation for global warming significantly damages the soundness of the ideological pro-market position which the American conservative movement has been embracing since the Reagan era and the end of the Cold War. The central contribution of human activities to the warming of our planet does not destroy the case for a market economy per se; it does, however, put a dent in the validity of the American Right's faith in the free market as the ultimate solution to all social, economic, and environmental problems. In effect, conceding defeat in the climate war would have devastating repercussions on the intellectual bearings of many conservative officials and activists. So far, for the most part, with a few notable exceptions like former Utah Governor Jon Huntsman and Arizona Senator John McCain, it has been a defeat too hard to swallow. While the scientific case of climate deniers has now been seriously discredited, their economic arguments will certainly continue to carry a lot of weight in American politics in the years to come.

Finally, the resilience of the climate change denial movement in the face of mounting scientific evidence also highlights the weaknesses of their proponents' own ideology. Broadly defined, the ideology of the proponents of strong climate action points to a willingness to adapt to the limitations imposed on modern civilisations by ecosystems and the biosphere. Yet, their reluctance to be more straightforward about the major cultural and behavioural changes that would inevitably stem from more ecologically-sensitive climate policies demonstrates that the implications of the policies they advocate are not completely developed. In addition, their irenic ${ }^{74}$ perception of the international community and its potential for well-coordinated, effective climate-related action does not bode well for the future. When it comes to laying out international measures to reduce greenhouse gas emissions, US proponents of strong climate-related action place a disproportionate burden on developed countries like the United States. Although from a historical and moral perspective this approach may seem justified, global warming remains first and foremost a global problem impossible to solve without the full participation of all countries, including developing countries. 


\section{BIBLIOGRAPHIE}

Allègre, Claude. L'imposture climatique ou la fausse écologie. Paris: Plon, 2010.

Allin, Craig W. The Politics of Wilderness Preservation. Fairbanks, AK: The University of Alaska Press, [1982], 2008.

Armey, Dick, and Matt Kibbe. Give Us Liberty: A Tea Party Manifesto. New York: Harper Collins, 2010.

Barnejee, Neela. "Mitt Romney Worked to Combat Climate Change as Governor." The Los

Angeles Times, June 13, 2012. Accessed April 29, 2013. http://articles.latimes.com/ 2012/jun/13/nation/la-na-romney-energy-20120613.

Boccia, Romina, Jack Spencer, and Robert Gordon Jr. "Environmental Conservation Based on Individual Liberty and Economic Freedom." The Heritage Foundation. Backgrounder n 2758 (January 8, 2013): 1-8. Accessed April 4, 2013. http:// www.heritage.org/research/reports/2013/01/environmental-conservation-based-onindividual-liberty-and-economic-freedom.

Borowski, Julie. "Earth Day Special: Private Property Protects the Environment." Freedom Works, 20 Apr. 2012. Accessed April 4, 2013. http://www.freedomworks.org/ blog/jborowski/private-property-protects-environment.

Brownstein, Ronald. The Second Civil War: How Extreme Partisanship Has Paralyzed Washington and Divided America. New York: Penguin, 2007.

Callicott, J. Baird. "From the Land Ethic to the Earth Ethic: Aldo Leopold and the Gaia Hypothesis." In Gaia in Turmoil: Climate Change, Biodepletion, and Earth Ethics in an Age of Crisis, edited by Eileen Crist, H. Bruce Rinker, and Bill McKibben, 177-194. Cambridge, MA: The MIT Press, 2009.

---. “5 Questions.” In Sustainability Ethics, edited by Ryne Raffaelle, Wade Robinson, and Evan Selinger, 57-70. Copenhagen: Automatic Press/VIP, 2010.

Cornwall Alliance. "An Evangelical Declaration on Global Warming." Accessed April 29, 2013. http://www.cornwallalliance.org/articles/read/an-evangelical-declaration-onglobal-warming/.

Courtillot, Vincent. Nouveau Voyage au centre de la Terre. Paris: Odile Jacob, [2009], 2011.

Crichton, Michael. "The Role of Science in Environmental Policy-Making." US Senate Committee on Environment and Public Works Hearing Statements, October 28, 2005. Accessed April 29, 2013. http://epw.senate.gov/hearing_statements.cfm?id=246766.

---. State of Fear. New York: Harper Collins, [2004], 2009.

Dunlop, Norton. "Federalism and Free Markets: The Right Environmental Agenda." The Heritage Foundation, March 9, 2006. Accessed April 29, 2013. http://www.heritage.org/ about/speeches/federalism-and-free-markets-the-right-environmental-agenda. 
Fleischer, Ari. Press Briefing, 7 May 2001. Accessed April 29, 2013. http://georgewbushwhitehouse.archives.gov/news/briefings/20010507.html.

Geman, Ben. "House GOP Leaders Pledge to Oppose Climate Tax." The Hill, November 15, 2012. Accessed April 29, 2013. http://thehill.com/blogs/e2-wire/e2-wire/268289house-gop-leaders-pledge-to-oppose-climate-tax.

Gerson, Michael. "Climate Change and the Culture War." The Washington Post, January 17, 2012. Accessed April 29, 2013. http://www.washingtonpost.com/opinions/climateand-the-culture-war/2012/01/16/gIQA6qH63P_story.html.

Goklany, Indur. "What to Do About Climate Change." Cato Institute Policy Analysis 609 (February 2008): 1-28. Accessed April 4, 2013. http://www.cato.org/sites/cato.org/files/ pubs/pdf/pa-609.pdf.

Gore, Al. The Assault on Reason. London: Bloomsbury, 2007. Kindle edition.

---. "Climate of Denial." Rolling Stone, June 22, 2011. Accessed April 30, 2013. http:// www.rollingstone.com/politics/news/climate-of-denial-20110622.

Gottlieb, Robert. Forcing the Spring: The Transformation of the American Environmental Movement. Washington, DC: Island Press, 1993.

Green, Kenneth P. "Not Going Away: America's Energy Security, Jobs and Climate

Challenges." Statement before the House Select Committee on Energy Independence and Global Warming, December 1, 2010. Accessed April 29, 2013. http://www.aei.org/ speech/energy-and-the-environment/climate-change/not-going-away-americasenergy-security-jobs-and-climate-challenges/.

Groves, Steven. "The 'Kyoto II' Climate Change Treaty: Implications for American Sovereignty." The Heritage Foundation. Copenhagen Consequences. Analysis of the 2009 Copenhagen UN Climate Change Conference $\mathrm{n}^{\circ} 5$ (November 17, 2009). Accessed July 23, 2013. http://www.heritage.org/research/reports/2009/11/the-kyoto-iiclimate-change-treaty-implications-for-american-sovereignty.

---. "National Sovereignty May Melt at Climate Conference." The Heritage Foundation. Commentary (December 4, 2009). Accessed July 23, 2013. http://www.heritage.org/ research/commentary/2009/12/national-sovereignty-may-melt-at-climate-conference.

---. "Why Does Sovereignty Matter to America?" The Heritage Foundation.

Understanding America (2010). Accessed July 23, 2013. http://www.heritage.org/ research/reports/2010/12/why-does-sovereignty-matter-to-america.

Grunwald, Michael. The New New Deal. New York: Simon \& Schuster, 2012.

Hoggan, James. Climate Cover-Up: The Crusade to Deny Global Warming. Vancouver: Greystone Books, 2009.

Inhofe, James. "Energy Tax Prevention Act: The Only End to Cap and Trade." Human Events, March 28, 2011. Accessed April 29, 2013. http://www.humanevents.com/ 2011/03/28/energy-tax-prevention-act-the-only-end-to-cap-and-trade/.

Isaac, Rael Jean. Roosters of the Apocalypse. Chicago: The Heartland Institute, 2012. 
Jacques, Peter J., Riley E. Dunlap, and Mark Freeman. "The Organization of Denial: Conservative Think Tanks and Environmental Scepticism.” Environmental Politics 17.3 (June 2008): 349-385.

James, Sallie. “A Harsh Climate for Trade: How Climate Change Proposals Threaten Global Commerce." Trade Policy Analysis 41 (September 2009): 1-20. Accessed April 4 2013. http://www.cato.org/sites/cato.org/files/pubs/pdf/tpa-041.pdf.

Johnson, Jason Scott. “A Looming Policy Disaster.” Regulation 31.3 (Fall 2008): 38-44. Accessed April 4, 2013. http://www.cato.org/sites/cato.org/files/serials/files/ regulation/2008/9/v31n3-1.pdf.

Krauthammer, Charles. "Carbon Chastity." The Washington Post, May 30, 2008. Accessed April 30, 2013. http://articles.washingtonpost.com/2008-05-30/opinions/ 36813249_1_socialism-carbon-chastity-co2into.

Loris, Nicolas, and Brett D. Schaefer. "Climate Change: How the United States Should Lead." The Heritage Foundation. Issue Brief $n^{\circ} 3841$ (January 24, 2013). Accessed April 4, 2013. http://www.heritage.org/research/reports/2013/01/climate-change-how-theus-should-lead.

Mann, Michael E. The Hockey Stick and the Climate Wars: Dispatches from the Front Lines. New York: Columbia University Press, 2012.

McKibben, Bill. “Climate of Denial.” Mother Jones, May/June 2005. Accessed April 30, 2013. http://www.motherjones.com/politics/2005/05/climate-denial.

Michaels, Patrick J. “Global Warming and Climate Change.” In Cato Handbook for Policymakers, $7^{\text {th }}$ ed., edited by David Boaz, 474-488. Washington, DC: Cato Institute, 2009.

Milloy, Steve. Green Hell: How Environmentalists Plan to Control your Life and What You Can Do to Stop Them. Washington, DC: Regnery Publishing Inc., 2009.

Mooney, Chris. The Republican War on Science. New York: Basic Books, [2005], 2006.

Morgan, Derrick. “A Carbon Tax Would Harm US Competitiveness and Low-Income Americans Without Helping the Environment." The Heritage Foundation.

Backgrounder $n^{\circ} 2720$ (August 21, 2012). Accessed July 23, 2013. http://

www.heritage.org/research/reports/2012/08/a-carbon-tax-would-harm-uscompetitiveness-and-low-income-americans-without-helping-the-environment.

Oreskes, Naomi. "Beyond the Ivory Tower: The Scientific Consensus on Climate Change." Science 306 (5702): 1686.

Oreskes, Naomi, and Erik M. Conway. Merchants of Doubt: How a Handful of Scientists Obscured the Truth on Issues from Tobacco Smoke to Global Warming. London: Bloomsbury, [2010], 2012.

Pinchot, Gifford. Breaking New Ground. Washington, DC: Island Press, [1947], 1987.

Pooley, Eric. The Climate Wars: True Believers, Power Brokers, and the Fight to Save the Earth. New York: Hyperion, 2010. 
Posner, Eric A., and Cass R. Sumstein. "Global Warming and Social Justice." Regulation 31.1 (Spring 2008): 14-20. Accessed April 4, 2013. http://www.cato.org/sites/cato.org/ files/serials/files/regulation/2008/2/v31n1-3.pdf.

Richards, Jay Wesley. "The Economy Hits Home: Energy and the Environment." Washington: The Heritage Foundation, undated. Accessed April 4, 2013. http:// thf_media.s3.amazonaws.com/2009/pdf/EconHitsHome_Environment.pdf.

Romney, Mitt. No Apology: Believe in America. New York: Saint Martin's Griffin, 2010.

Scissors, Derek. "China Will Follow the United States: A Climate Change Fable." The Heritage Foundation. WebMemo n² 2327 (March 5, 2009). Accessed July 23, 2013. http:// www.heritage.org/research/reports/2009/03/china-will-follow-the-us-a-climatechange-fable.

Stimson, James A. Tides of Consent: How Public Opinion Shapes American Politics. New York: Cambridge University Press, [2004], 2009.

Taylor, Jerry. "Environmental Policy." In Cato Handbook for Policymakers, $7^{\text {th }}$ ed., edited by David Boaz, 463-474. Washington, D.C.: Cato Institute, 2009.

Will, George F. "Global Warming Advocates Ignore the Boulders." The Washington Post, February 21, 2010. Accessed April 30, 2013. http://newstrust.net/stories/853779/ toolbar.

Wing, Nick. "John Shimkus, GOP Rep. Who Denies Climate Change on Religious Grounds, Could Lead House Environmental Policy." The Huffington Post, November 13, 2010. Accessed April 30, 2013. http://www.huffingtonpost.com/2010/11/13/johnshimkus-climate-change_n_782664.html.

Winner, Langdom. The Whale and the Reactor: A Search for Limits in an Age of High Technology. Chicago, IL: Chicago University Press, 1986.

Zernike, Kate. Boiling Mad: Inside Tea Party America. New York: Times Books, 2010.

\section{NOTES}

1. Claude Allègre, L'imposture climatique ou la fausse écologie (Paris: Plon, 2010). Vincent Courtillot, Nouveau Voyage au centre de la Terre (Paris: Odile Jacob 2011).

2. The lobbying activities of the Koch brother (Charles G. Koch and David H. Koch) who own Koch Industries have received considerable media attention over the last few years. For several decades, they have been funding various free-market and libertarian advocacy groups with a view to shaping the decision-making process.

3. Among the most prominent think tanks involved in the climate change denial movement are the American Enterprise Institute, the George C. Marshall Institute, the Heartland Institute, the Cato Institute, and the Heritage Foundation. This list is far from exhaustive.

4. James A. Stimson, Tides of Consent: How Public Opinion Shapes American Politics (Cambridge, UK; New York: Cambridge University Press, 2009), 45.

5. Craig W. Allin, The Politics of Wilderness Preservation (Fairbanks, AK: The University of Alaska Press, 2008), 3-24.

6. Robert Gottlieb, Forcing the Spring: The Transformation of the American Environmental Movement (Washington, DC: Island Press, 1993), 117-161. 
7. See the EPA website for the complete text of the Clean Air Act: http://www.epa.gov/air/caa, last updated February 17, 2012.

8. See the EPA website for the complete text of the Clean Water Act: http://www.epa.gov/ lawsregs/laws/cwa.html, last updated April 16, 2013.

9. See the website of the National Oceanic and Atmospheric Administration for the complete text of the Endangered Species Act: http://www.nmfs.noaa.gov/pr/laws/esa/, last updated March 7, 2013.

10. See the EPA website for a summary of the history of the EPA: http://www2.epa.gov/ aboutepa/epa-history, last updated May 1, 2013.

11. It is noteworthy that the land management policies sought by the Cato Institute and the Heritage Foundation bear an uncanny resemblance to those of the era predating federal conservation: Gifford Pinchot and his followers set out to rationalize the way in which natural resources were exploited through scientifically-based management under federal supervision. Pinchot's autobiography makes it clear that his goal had been to remedy the havoc wreaked by easy access to property, free enterprise, and unregulated use of natural resources. See Gifford Pinchot, Breaking New Ground (Washington, DC: Island Press, 1987), 509. Pinchot understood fully well that federal conservation hinged on extensive public ownership and a reversal of the privatizing process initiated by the Founding Fathers. As the bureaucratic apparatus of federal conservation was reinforced extensively in the 1960s and 1970s, Pinchot's perspective, the anathema of small-government conservatives, remained the order of the day. According to the Heritage Foundation's conservation experts, environmental regulations are just one aspect of "the insatiable growth of the regulatory state." What is more, they argue, active public management of natural resources is bound to be self-defeating, inefficient and inferior to the outcomes produced by market mechanisms. See Romina Boccia, Jack Spencer, and Robert Gordon Jr., "Environmental Conservation Based on Individual Liberty and Economic Freedom," The Heritage Foundation, Backgrounder n`2758 (January 8, 2013): 2, accessed April 4, 2013, http:// www.heritage.org/research/reports/2013/01/environmental-conservation-based-on-individualliberty-and-economic-freedom. Their experts claim that, except for Yosemite and Yellowstone national parks, the federal government would be well-advised to privatize the public domain completely (Ibid., 3). The libertarian Cato Institute has endorsed the same position (Taylor "Environmental Policy," 463-464).

12. Chris Mooney, The Republican War on Science (New York: Basic Books, 2006), 30-32.

13. Naomi Oreskes and Erik M. Conway, Merchants of Doubt: How a Handful of Scientists Obscured the Truth on Issues from Tobacco Smoke to Global Warming (London: Bloomsbury, 2012), 6.

14. Ibid., 169-215.

15. Al Gore, The Assault on Reason (London: Bloomsbury, 2007), Kindle edition, 199.

16. Al Gore, "Climate of Denial," Rolling Stone, June 22, 2011, accessed April 30, 2013, http:// www.rollingstone.com/politics/news/climate-of-denial-20110622.

17. Mann has been the unfortunate target of vicious ad hominem attacks by climate change deniers who fault him for the "hockey-stick" graph which highlights the abnormal rise in temperatures in the last decades of the $20^{\text {th }}$ century. See for example http:// www.businessinsider.com/michael-mann-describes-life-as-a-target-2013-3, last updated March 27, 2013.

18. Michael E. Mann, The Hockey Stick and the Climate Wars: Dispatches from the Front Lines (New York: Columbia University Press, 2012), 3-4.

19. Cap and trade is defined as a market-based plan to reduce carbon emissions in which the government sets a cap to limit emissions and issues pollution credits which companies can buy and sell as they wish, the point being that those that pollute less can sell their extra credits to those that pollute more so that overall emissions do not rise above the cap. Ultimately the 
government imposes fines to companies who do not abide by this framework. Cap and trade was at the heart of the Waxman-Markey Bill that failed in Congress in 2009.

20. "Oil and Gas: Lobbying, 2012," Center for Responsive Politics, accessed May 2, 2013, http:// www.opensecrets.org/industries/lobbying.php?cycle=2012\&ind=E01.

21. Eric Pooley, The Climate Wars: True Believers, Power Brokers, and the Fight to Save the Earth (New York: Hyperion, 2010), 186.

22. "Influence and Lobbying: Oil and Gas," Center for Responsive Politics, accessed May 2, 2013, http://www.opensecrets.org/industries/indus.php?ind=E01.

23. "Oil and Gas Lobbying, 2012."

24. “Environment: Lobbying, 2012," Center for Responsive Politics, accessed May 2, 2013, http:// www.opensecrets.org/industries/lobbying.php?cycle=2012\&ind=Q11.

25. Peter J. Jacques, Riley E. Dunlap and Mark Freeman, “The Organization of Denial:

Conservative Think Tanks and Environmental Scepticism," Environmental Politics 17.3 (June 2008): 360.

26. Nick Wing, "John Shimkus, GOP Rep. Who Denies Climate Change on Religious Grounds, Could Lead House Environmental Policy," The Huffington Post, November 13, 2010, accessed April 30, 2013, http://www.huffingtonpost.com/2010/11/13/john-shimkus-climate-

change_n_782664.html. “An Evangelical Declaration on Global Warming," Cornwall Alliance, accessed April 29, 2013, http://www.cornwallalliance.org/articles/read/an-evangelicaldeclaration-on-global-warming/.

27. Julie Borowski, "Earth Day Special: Private Property Protects the Environment," Freedom Works, April 20, 2012, accessed April 4, 2013, http://www.freedomworks.org/blog/jborowski/ private-property-protects-environment. Norton Dunlop, "Federalism and Free Markets: The Right Environmental Agenda," The Heritage Foundation, March 9, 2006, accessed April 29, 2013, http://www.heritage.org/about/speeches/federalism-and-free-markets-the-rightenvironmental-agenda.

28. Jay Wesley Richards, “The Economy Hits Home: Energy and the Environment" (Washington: The Heritage Foundation, Undated), 14, accessed April 4, 2013, http:// thf_media.s3.amazonaws.com/2009/pdf/EconHitsHome_Environment.pdf.

29. Kate Zernike, Boiling Mad: Inside Tea Party America (New York: Times Books, 2010), 37.

30. Dick Armey and Matt Kibbe, Give Us Liberty: A Tea Party Manifesto (New York: Harper Collins, 2010), 90-91.

31. Ibid., 95-96.

32. J. Baird Callicott, "From the Land Ethic to the Earth Ethic: Aldo Leopold and the Gaia Hypothesis," in Gaia in Turmoil: Climate Change, Biodepletion, and Earth Ethics in an Age of Crisis, ed. Eileen Crist, H. Bruce Rinker, and Bill McKibben (Cambridge, MA: The MIT Press, 2009), 191. 33. Oreskes and Conway, Merchants, 238.

34. See the website of the United States Climate Action Partnership, http://www.us-cap.org/. 35. Michael Gerson, "Climate Change and the Culture War," The Washington Post, January 17, 2012, accessed April 29, 2013, http://www.washingtonpost.com/opinions/climate-and-theculture-war/2012/01/16/gIQA6qH63P_story.html.

36. Michael Crichton, State of Fear (New York: Harper Collins, 2009).

37. Michael Crichton, "The Role of Science in Environmental Policy-Making," US Senate Committee on Environment and Public Works Hearing Statements, October 28, 2005, accessed April 29, 2013, http://epw.senate.gov/hearing_statements.cfm?id=246766.

38. George F. Will, "Global Warming Advocates Ignore the Boulders," The Washington Post, February 21, 2010, accessed April 30, 2013, http://newstrust.net/stories/853779/toolbar. 39. Steve Milloy, Green Hell: How Environmentalists Plan to Control your Life and What You Can Do to Stop Them (Washington, DC: Regnery Publishing Inc., 2009), 234. 
40. Charles Krauthammer, "Carbon Chastity," The Washington Post, May 30, 2008, accessed April 30, 2013, http://articles.washingtonpost.com/2008-05-30/opinions/36813249_1_socialismcarbon-chastity-co2into.

41. Neela Barnejee, "Mitt Romney Worked to Combat Climate Change as Governor," The Los Angeles Times, June 13, 2012, accessed April 29, 2013, http://articles.latimes.com/2012/jun/13/ nation/la-na-romney-energy-20120613.

42. Mitt Romney, No Apology: Believe in America (New York: Saint Martin's Griffin, 2010), 243.

43. Ronald Brownstein, The Second Civil War: How Extreme Partisanship Has Paralyzed Washington and Divided America (New York: Penguin, 2007), 11-13.

44. Naomi Oreskes, "Beyond the Ivory Tower: The Scientific Consensus on Climate Change," Science 306 (5702): 1686.

45. James Hoggan, Climate Cover-Up: The Crusade to Deny Global Warming (Vancouver: Greystone Books, 2009), 118.

46. Kenneth P. Green, "Not Going Away: America's Energy Security, Jobs and Climate Challenges," Statement before the House Select Committee on Energy Independence and Global Warming, December 1, 2010, accessed April 29, 2013, http://www.aei.org/speech/energy-and-theenvironment/climate-change/not-going-away-americas-energy-security-jobs-and-climatechallenges/.

47. Indur Goklany, "What to Do About Climate Change," Cato Institute Policy Analysis 609 (February 2008): 3, accessed April 4, 2013, http://www.cato.org/sites/cato.org/files/pubs/pdf/ pa-609.pdf.Patrick J. Michaels, "Global Warming and Climate Change," in Cato Handbook for Policymakers, $7^{\text {th }}$ ed.,ed. David Boaz (Washington, DC: Cato Institute, 2009), 475. Eric A. Posner and Cass R. Sumstein, "Global Warming and Social Justice," Regulation 31.1 (Spring 2008): 19, accessed April 4, 2013, http://www.cato.org/sites/cato.org/files/serials/files/regulation/2008/2/ v31n1-3.pdf.

48. Sallie James, “A Harsh Climate for Trade: How Climate Change Proposals Threaten Global Commerce," Trade Policy Analysis 41 (September 2009): 4, accessed April 4, 2013, http:// www.cato.org/sites/cato.org/files/pubs/pdf/tpa-041.pdf.

49. Derrick Morgan, "A Carbon Tax Would Harm US Competitiveness and Low-Income Americans Without Helping the Environment," The Heritage Foundation, Backgrounder n²720 (August 21, 2012), 4, accessed July 23, 2013, http://www.heritage.org/research/reports/2012/08/a-carbontax-would-harm-us-competitiveness-and-low-income-americans-without-helping-theenvironment.

50. Ibid., 5.

51. Nicolas Loris and Brett D. Schaefer, "Climate Change: How the United States Should Lead," The Heritage Foundation, Issue Brief n³841 (January 24, 2013), accessed April 4, 2013, http:// www.heritage.org/research/reports/2013/01/climate-change-how-the-us-should-lead. 52. Steven Groves, “The 'Kyoto II’ Climate Change Treaty: Implications for American Sovereignty," The Heritage Foundation, Copenhagen Consequences, Analysis of the 2009 Copenhagen UN Climate Change Conference $n^{\circ} 5$ (November 17, 2009), 3, accessed July 23, 2013, http://www.heritage.org/research/reports/2009/11/the-kyoto-ii-climate-change-treatyimplications-for-american-sovereignty.

53. Steven Groves, "National Sovereignty May Melt at Climate Conference," The Heritage Foundation, Commentary (December 4, 2009), accessed July 23, 2013, http://www.heritage.org/ research/commentary/2009/12/national-sovereignty-may-melt-at-climate-conference.

54. Derek Scissors, "China Will Follow the United States: A Climate Change Fable," The Heritage Foundation, WebMemo n 2327 (March 5, 2009), 1, accessed July 23, 2013, http:// www.heritage.org/research/reports/2009/03/china-will-follow-the-us-a-climate-change-fable. 55. Pooley, Climate, 429-431.

56. Groves, "National Sovereignty". 
57. Steven Groves, “Why Does Sovereignty Matter to America?," The Heritage Foundation, Understanding America, 2010, 7-8, accessed July 23, 2013, http://www.heritage.org/research/ reports/2010/12/why-does-sovereignty-matter-to-america.

58. Ari Fleischer, "Press Briefing," May 7, 2001, accessed April 29, 2013, http://georgewbushwhitehouse.archives.gov/news/briefings/20010507.html.

59. James Inhofe, "Energy Tax Prevention Act: The Only End to Cap and Trade," Human Events, March 28, 2011, accessed April 29, 2013, http://www.humanevents.com/2011/03/28/energy-taxprevention-act-the-only-end-to-cap-and-trade/.

60. "No Climate Tax," Americans for Prosperity, accessed May 2, 2013, http://

www.noclimatetax.com/.

61. Ben Geman, "House GOP Leaders Pledge to Oppose Climate Tax," The Hill, November 15, 2012, accessed April 29, 2013, http://thehill.com/blogs/e2-wire/e2-wire/268289-house-gop-leaderspledge-to-oppose-climate-tax.

62. Rael Jean Isaac, Roosters of the Apocalypse (Chicago: The Heartland Institute, 2012), 26.

63. Ibid., 2.

64. Ibid., 41.

65. Milloy, Green Hell, 33.

66. J. Baird Callicott, " 5 Questions," in Sustainability Ethics, ed. Ryne Raffaelle, Wade Robinson, and Evan Selinger (Copenhagen: Automatic Press/VIP, 2010), 62.

67. Gore, Assault, 214.

68. Pooley, Climate, 349.

69. Bill McKibben, “Climate of Denial," Mother Jones, May/June 2005, accessed April 30, 2013, http://www.motherjones.com/politics/2005/05/climate-denial.

70. Pooley, Climate, 360.

71. Michael Grunwald, The New New Deal (New York: Simon \& Schuster, 2012), 352-379.

72. Stimson, Tides, 44.

73. "Dead Aim: Joe Manchin for West Virginia," accessed May 2, 2013, http://www.youtube.com/ watch?v=xIJORBRPOPM.

74.

\section{RÉSUMÉS}

The concerted effort to discredit the scientific consensus over man-made global warming has been continuing for two decades in the United States, and shows no sign of weakening. It is very often described as an attempt on the part of corporate America, most notably the fossil fuel industries, to hinder governmental regulations on their activities. While emphasising this dimension of the US climate denial movement, this article also aims to show the complexity of the movement, rather than the mere defence of the narrowly-defined and short-term economic interests of the oil and gas industries, by shedding light on two additional factors which have been instrumental in blocking strong climate action. First, climate denial stems from the strong ideological commitment of small-government conservatives and libertarians to laisser-faire and their strong opposition to regulation. Second, in order to disarm their opponents, US climate deniers often rest their case on the defence of the American way of life, defined by high consumption and ever-expanding material prosperity. It is the contention of this article, 
therefore, that the US climate denial movement is best understood as a combination of these three trends.

INDEX

Keywords : climate change, conservatism, consumerism, ecology, environmentalism, free market, global warming, ideology, libertarianism, Republican party, think tanks.

\section{AUTEURS}

JEAN-DANIEL COLLOMB

Maître de conférences, Université Jean Moulin, Lyon 3 (France),jean-daniel.collomb@univlyon3.fr 